\title{
Renewal System of the Social Work Punishment
}

\author{
Wafda Vivid Izziyana ${ }^{1}$, Arief Budiono ${ }^{2}$, and Arham Anom Besari ${ }^{3}$ \\ Faculty of Law, Universitas Muhammadiyah Ponorogo. Indonesia ${ }^{1-3}$ \\ \{wafda.vivid@yahoo.com ${ }^{1}$, areevhims@gmail.com ${ }^{2}, \underline{\left.\text { arhamanom1@gmail.com }^{3}\right\}}$
}

\begin{abstract}
Punishment becomes a problem in the law system in Indonesia. The purpose of the punishment system is a form of protection for all Indonesian as stated in the Preamble of Constitution 1945 (UUD 1945). Punishment should consider humanism. The effectiveness of imprisonment is questionable, especially the negative effect. The prison condition causes some critics. Prison usually used as the education side for the criminals who gave birth the professional criminals. Punishment verdict does not necessarily in prison. If someone goes to jail, he will be a state burden and also the prison should serve so many facilities. Social work punishment should give benefit than imprisonment. The positive law regulation in the future (iusconstitutum) especially the regulation about social work punishment can be formulated better by protecting the society and rehabilitating theperpetrators of the crime as the main purpose. It is needed to formulate rightly about social work punishment,so they act effectively and reach the goal appropriately.
\end{abstract}

Keywords: Renewal, Punishment System, Social Work.

\section{Introduction}

One of the law aspects is about the punishment, which the process known as the criminal law [1]. Andi Hamzah said that punishment is criminal detention or penalization [2]. The phenomena of punishment system become a problem in Indonesian law system. The purpose of the punishment should consider humanism.

The criminal sanction used is in the form of imprisonment or confinement [3]. Punishment problem is not an easy problem, based on Sudarto, punishment needs deep attention and carefully acts [4]. The prison condition causes some critics in its implementation of imprisonment. The sanctions also cause a negative effect, which is dehumanization. Besides, the lack of effective implementation of imprisonment, there is another negative aspect of imprisonment that cannot be calculated, over capacity[3].

Social work punishment for the perpetrator of the minor crime can fulfill the element of coaching and give protection to society[5]. The punishment of social work has never been known and never been applied in the Indonesian regulation and statute. But it is possible to be applied remembering the variety of benefits of this punishment that never got from the imprisonment especially for the perpetrator of the minor crime.

Even the punishment of the social works do not know and applied yet but it has been tried to introduced trough the KUHP revision draft 2010 in 86 clause which is social work 
punishment is the alternative of punishment for the deprivation of liberty besides the short imprisonment.

\section{Result and discussion}

How to integrate the social work punishment in Indonesian law system?In this case, integration is combining the punishment with the social work crime to the positive law system and the regulation in Indonesia. Punishment is very important to do, remember that thefail to make injustice is causedby the criminal will get the harder punishment than other, or vice versa [6]. Legislative has the task to maintain the limit of punishment (the limit of sentencing), while the judiciary maintain the level of punishment (the level of sentencing). This condition should be fair considering many factors so it can be called as the proper punishment (proper sentence).

Lawrence M. Friedman said that there are three elements from the law system; they are: first, law structure, the regulation that shows how the law should be run on the formal track. Second, the law substation is in the form of rules, norms, and regulation that bound a legal force. The third element is the legal culture. It is the law that suitable in society [7].

An integrative theory of punishment is the combination of many punishment theories that most appropriate to be applied in Indonesia. But by using sociology, ideology, and philosophical juridical which is based on the core assumption, it can be said that the criminal act is an interruption for the balancing, harmonious, and people's live. Punishment itself is to rehabilitate the individual and social damage that caused by the criminal act [8].

Etymologically the term of social work punishment consists of two words; they are punishment and social work. A social work penalty is a criminal form in which the criminal is served by a convicted person by performing a specified social work[3]. Social work penalty is a criminal type that must be served by convicts outside the institution by doing social works; this social work penalty is not paid or paid under the provisions because of its nature as a criminal (work as a penalty). This type of social work is a penalty that never regulated before in the positive law in Indonesia, both in KUHP and another side of KUHP [1].

Social work penalty is a consequence of the acceptance of criminal law "daad daderstraafrecth" as long as the development of imprisonment alternative. For the criminal of social work, it can be felt that they lose their independence.

The benefit of social work, based on Eryna Ganda Nugraha, is a little more stigmatization process that being a side effect of the imprisonment. European applied the social work type, but it is in the form of a certain criminal act. Social work penalty can only be applied to less serious crimes [3]. Implementation of social work crime for perpetrators of underage crime must also consider the existence of prohibition rules for minors who under the labor law are prohibited from doing work. Social history also needed to give a mark whether the criminal can face social work punishment mentally and physically.

Based on Konrad Buczowsky in his book entitled "Criminality and Criminal Justice in contemporary Poland, Sociological perspective", said that in Poland KUHP, the social work is similar with the social work which is the limitation of independence where there a must for the criminal to work for the society interest under the supervision [9].

German applied the social work for the alternative of imprisonment for the criminal if he cannot pay the fine [10]. Commonly, social work punishment will not be applied for the bad criminal record.

Hazairin said after he compared the variety of punishment as the alternative of punishment in an Indonesian prison, he thinks that it need another type of punishment for the criminal, the 
social useful works or community service order. It is based on the consideration of penology perspective, the punishment type for the criminal should reach the purpose of penalty, both in the context of common and special prevention, but in fact the human treatment system is more effective to decrease the possible repetition of a crime (recidivism) than another type of punishment [11].

Social work punishment is based on the concept of individualization punishment as designed in the Indonesian Criminal Code Bill (RUU KUHP). It can be applied in Indonesia because theoretically, philosophically, empirically, and juridical is appropriate with the fifth precept of Pancasila, social justice for all the people of Indonesia.

In applying social work punishment, the criminal is prosecuted for working hard during the period of punishment [12]. So, it can be said that the social work is the element of punishment and prevention for the criminal after getting the prison.

Based on the problem above, Indonesia applied forsocial work as the short punishment so that the criminal can be spared from the stigmatization and prisonization. Besides that, the criminal who is getting short punishment does not join the coaching maximally in prison. This social work is appropriate for the first criminal [3]. Such as the international world, Indonesia also tries to look for the alternative for the punishment,especially for the short punishment. This kind of punishment is not effective for the philosophical aspect, humanity and economically because it has a negative effect both for the convicted and defendant. It is needed a law penalty to integrate the social work punishment into Indonesian law system. Sudarto definessocial work punishment as an effort to realize the regulations based on the circumstances and situation. It also includes the policy through the authorized bureau to set up the regulations that used to express what is contained and envisioned [4].

The crime prevention and mitigation with the punishment including among others social work crime and integrate into the law legal system. Based on Barda Nawawi Arief, the functionalization and operationalization were done in some stages; they were formulation (legislative policy), application (judicative/judicial), and execution (executive and administrative) [8]. By having the formulate stage, the efforts do not only for the law enforcer but also for the law enforcement apparatus (legislative apparatus). Legislative policy is the most strategic stage to reduce crime. It is because the weakness of the policy can inhibit the effort of reducing crime in execution steps.

In a book entitled Social Defense, A Modern Approach to Criminal Problems, Marc Ancel's book, cited by Barda Nawawi Arief said that "Between the study of criminological factors on the one hand, and the legal technique on the others there is room for a science which observes legislative phenomenon and for a rational art within which scholar and practitioners, criminologist and lawyers can come together, not as antagonist or in fratricidal strife, but as follow workers engaged in a common task, which is first and foremost to bring into effect a realistic, humane, and healthily progressive penal policy" [8].

By joining the concept that the formulation stage is the most strategic stage for the law apparatus so the bachelor, practitioners, criminology and legal expert should work together to get a realistic policy, humanist, and progressive social work punishment. Based on Marc Ancel opinion above, it can be correlated with the social worker's aim and purpose, so that the idea or thought about the integration of social work punishment in the Indonesian law system is to get the realistic, humanism, and progressive sanction policy.

By having this idea, so that the future positive law will come (iusconstitutum) especially for the social work punishment can be organized better with appropriate vision and suitable with the main purpose, giving a punishment that protects the community and rehabilitates the perpetrator. 
So, it needs the appropriate concept of social work punishment then it can be applied effectively and achieve the goal.

The concepts should consider the culture and sociology condition of the Indonesian so that it can be an appropriate law based on the right fact. The formulation needs a transformation of the criminal and punishment system that encourage the spirit to find out the other humanism alternative. In this stage, the criminal concept is shifted philosophically from the retaliating to coaching (treatment philosophy)[13]. To be integrated intoIndonesia, the social work punishment should be formulated by the authorities so that it can be enforced in Indonesian law. The integration of social work punishment into Indonesian law can be formulated in the legislation level and being a renewal of law.

As it is known that the criminal law in Indonesia is the legacy of the Dutch Colonial at 19 century and formally it is questionable for the effectiveness of the law application on clause II in rules of the transition of Constitution 1945 in sociological and philosophical even the history factors[13], it means that the application of law will be effective if it is valid. Supported by the community and appropriate with the value and social goal, Teuku Muhammad said that one of the requirements of good law enforceability is the law should consider with the aspiration and social need [14].

If it is seen carefully, the criminal penalty in Indonesia cannot fulfill the requirement because of the colonial soul is different from social value. Orientation is needed for the social work punishment so that it can be formulated and integrated into national law system philosophically, culturally, and then it can be a base. The Reformation, in fact,consists of the effort of reevaluation of the value that is a base and give the norm of social value for the social work punishment. It is urgent to do considering the criminalization does not reduce the crime rate, and it proves by the overload of capacity in the Indonesia prison even the new prison has been built.

Beside the reformulation, the conceptual and rational approach is needed for the social work punishment,and it should really stop the dangerous activities then it also integrated with the social interest thatconsists of the protection aspect for the society without getting the stigmatization and maintain the integrity of the human dignity of the individual as a humanistic approach.

This integrative process is needed so that the punishment raises the awareness of the offenders of human value by getting the social work punishment and it is an educative process for the criminal. The related institution should be prepared technically, how to social work punishment work and how to be supervised. The registration will be in the right record,and it will not run without coordination. The record of the criminal should in the right record, for example the serial murder only get the social work punishment. All about the record should be prepared in detail.

\section{Conclusion}

Punishment is not usually in the form of imprisonment; the social work punishment is more useful. The positive law will be released (iusconstitutum) especially about the social work punishment that formulated better and appropriate with the vision and main goal, protect the society and rehabilitate the criminal. The formulation used to formulate correctly about social work punishment so it can be used effectively and reach the goals. 


\section{References}

[1] S. D. Ardiani, "Kebijakan Pidana Kerja Sosial Dalam Rangka Penuangan Ide Individualisasi Pidana (Studi Terhadap Alternatif Pidana Perampasan Kemerdekaan Jangka Pendek)," Universitas Negeri Semarang., Semarang, 2003.

[2] T. Setiady, Pokok-Pokok Hukum Penitensier Indonesia. Bandung: Alfabeta, 2010.

[3] Tongat, Pidana Kerja Sosial Dalam Pembaharuan Hukum Pidana Indonesia. Jakarta: Djambatan, 2001.

[4] Sudarto, Hukum Pidana Dan Perkembangan Masyarakat. Bandung: Sinar Baru, 1984.

[5] F. I. Febriansyah, "Impact of Ratification of Government Regulations Substituting Law Number 2 of 2017 Becomes Act on Society in Running Activities of Islamic Community Organizations in Indonesia," Al-Hayat J. Islam. Educ., vol. 2, no. 2, pp. 193-201, 2018.

[6] C. Huda, Dari Tiada Pidana Tanpa Kesalahan Menuju Kepada Tiada Pertanggung Jawaban Pidana Tanpa Kealahan. Tinjauan Kritis Terhadap Teori Pemisahan Tindak Pidana Dan Pertanggungjawaban Pidana. Jakarta: Kencana Prenada Media, 2006.

[7] L. M. Friedman, Age discrimination law: Some remarks on the American experience. Oxford: Hart Publishing Oxford, 2003.

[8] N. A. Barda, Bunga Rampai Kebijakan Hukum Pidana. Bandung: Citra Aditiya Bakti, 1996.

[9] K. Buczkowski, Czarnecka-Dzialuk, W. B., Klaus, A. Kossowska, and D. Wójcik, Criminality And criminal Justice In Contemporary Poland, Sociological Perspectives. London: Routledge Taylor And Francis Group, 2015.

[10] M. H. Anis, "Ide Pidana Kerja Sosial Dan Implementasinya Dalam Kebijakan Formulasi Hukum Pidana Untuk Anak Di Indonesia,” Pasca Sarjana Undip, Semarang, 2003.

[11] Z. Ninik, "Hazairin Dan Penghapusan Pidana Penjara Pendek," J. Al Ahkam, vol. 26, no. $2,2016$.

[12] Hazairin, “Tujuh Serangkai Tentang Hukum.” Bina Aksara, Bandung, 1981.

[13] J. Asshiddiqie, Pembenaran Hukum Pidana Indonesia: Studi Tentang Bentuk Bentuk Pidana Dalam Tradisi Figh Dan Relevansinya Bagi Usaha Pembaharuan KUHP Nasional. Bandung: Angkasa, 1996.

[14] M. R. Teuku, Peranan Hukum Islam Dalam Pembinaan Hukum Nasional. Yogyakarta: Bina Aksara, 1983. 